\title{
Fertilizer Placement Affects Growth, Fruit Yield, and Elemental Concentrations and Contents of Tomato Plants
}

\author{
D.G. Mortley ${ }^{1}$, C.B. Smith ${ }^{2}$, and K.T. Demchak ${ }^{3}$ \\ Department of Horticulture, The Pennsylvania State University, University Park, PA 16802 \\ Additional index words. broadcast fertilizer, banded fertilizer, sidedressed fertilizer, nitrogen, phosphorus, potassium, \\ Lycopersicon esculentum
}

Abstract. The effects of fertilizer placement on growth and nutrient uptake of 'Count II' tomatoes (Lycopersicon esculentum Mill.) were evaluated in a 3-year study. Fertilizer was applied broadcast at two rates or banded in two bands at two widths or in four bands, or applied in combinations of sidedressing or broadcasting with banding of $\mathrm{N}$, $\mathrm{P}$, and $\mathrm{K}$ at 56, 112, or $224 \mathrm{~kg} \cdot \mathrm{ha}^{-1}$ each. Total fruit yield for the $112 \mathrm{~kg} \cdot \mathrm{ha}^{-1}$ banded treatment was $24 \%$ higher than that for the same rate broadcast and similar to yield for $224 \mathrm{~kg} \cdot \mathrm{ha}^{-1}$ broadcast. Treatments involving combined placements, wider bands, or four bands produced yields similar to that for $112 \mathrm{~kg} \cdot \mathrm{ha}^{-1}$ banded, but the $56 \mathrm{~kg} \cdot \mathrm{ha}^{-1}$ banded with two $56 \mathrm{~kg} \cdot \mathrm{ha}^{-1}$ sidedressings had the highest yield. Leaf concentrations and plant contents of $\mathrm{N}$, P, and $\mathrm{K}$ and percentage recovery of quantities applied were generally higher in treatments involving banding or sidedressing when compared to broadcasting. Leaf $\mathrm{Mn}$ was much higher in banded or sidedressed than for broadcast treatments but was lower when $112 \mathrm{~kg} \cdot \mathrm{ha}^{-1}$ was applied in four bands than in two. Only with $\mathrm{Mg}$ and $\mathrm{Mn}$ were leaf concentrations and plant contents highly correlated. With $112 \mathrm{~kg} \cdot \mathrm{ha}^{-1}$ banded, $31.2 \%$ of the $\mathrm{N}, 5.8 \%$ of the $\mathrm{P}$, and $44.7 \%$ of the $\mathrm{K}$ applied were taken up, compared to $12.5 \%, 2.3 \%$, and $17.2 \%$, respectively, for double this rate broadcast.

There have been relatively few fertilizer placement experiments with vegetable crops where nutrient uptake was determined through the use of plant analysis. Hipp (1970) found that band placement increased tomato yields, when compared to broadcast at the same rate and that banding enhanced $\mathrm{P}$ uptake. Jones and Warren (1954) and Locascio et al. (1960) also showed that banding fertilizer increased uptake of P. In an extensive series of vegetable experiments including tomatoes, Smith et al. (1990) found that banding fertilizer or combining other placements with banding produced higher yields than broadcasting the same quantity of fertilizer and was comparable to broadcasting a doubled quantity. Here, leaf $\mathrm{P}$ was higher with banded placement compared to broadcast, while leaf Mn was substantially increased by banding. Total plant nutrient content [as defined by Farhoomand and Peterson (1968)] was reported as being a more precise means of measuring nutrient uptake than leaf concentration in snapbeans (Palaniyandi and Smith, 1978) or calceolaria (Calceolaria crenatifolia) (White and Biernbaum, 1984). Jarrell and Beverly (1981) proposed that data on total uptake and total dry matter be coupled with consideration of concentrations in interpreting plant analysis. Another means of looking at efficiency in uptake is to compare total uptake with quantities applied. Brown and Carolus (1965), working with asparagus, found that a much larger percentage of $\mathrm{N}$ and $\mathrm{K}$ were recovered by the plant tissue than P. Sweeney et al. (1987) found that $54 \%$ to $75 \%$ of the $\mathrm{N}$ in tomato plants and fruits originated in the fertilizer when ammonium nitrate was applied. The greatest amount of $\mathrm{N}$ from fertilizer was shown to be $40 \%$ to $50 \%$ of the total tomato plant $\mathrm{N}$ in experiments of Miller et al. (1981). Hills et al. (1983) reported that recovery of labelled

\footnotetext{
Received for publication 16 Apr. 1990. Contribution no. 164 in Dept. of Horticulture series. Supported in part by research funds administered by the Pennsylvania Dept. of Agriculture. The cost of publishing this paper was defrayed in part by the payment of page charges. Under postal regulations, this paper therefore must be hereby marked advertisement solely to indicate this fact. 'Research Fellow, Plant Nutrition. Present address: Dept. of Plant Science, Tuskegee Inst., Tuskegee, AL 36088.

${ }^{2}$ Professor Emeritus of Plant Nutrition.

${ }^{3}$ Research Aide, Plant Nutrition.
}

$\mathrm{N}$ from fertilizer was $27 \%$ for tomato compared to $57 \%$ for corn.

This study was carried out to determine growth responses from a range of fertilizer placement treatments and to evaluate the efficiency in nutrient uptake by determining leaf concentrations, total above-ground plant contents, and recoveries of soilapplied fertilizers.

\section{Materials and Methods}

Experiments were conducted at the Horticultural Research Farm, Rock Springs, Pa., in 1986-88 in a different field each year. 'Count II' tomatoes were grown on Hagerstown silt loam (Typic Hapludalf) in a randomized complete block design, using nine fertilizer treatments with four replications. Each three-row plot measured $4.6 \times 6.1 \mathrm{~m}$, of which the center row was used for data collection. Soil samples were taken each year from each replication before planting and analyzed for $\mathrm{pH}$, available $\mathrm{P}$, and exchangeable $\mathrm{K}, \mathrm{Mg}$, and $\mathrm{Ca}$ (Dahnke, 1988). Soil analysis results from the three sites in the three respective years were: $\mathrm{pH}-6.2,6.4$, and $6.5 ; \mathrm{P}-124,131$, and $175 \mathrm{~kg} \cdot \mathrm{ha}^{-1}$; and, in percent saturation, $\mathrm{K}-2.4,3.4$, and 4.8; $\mathrm{Mg}-8.2,11.2$, and 16.8; and $\mathrm{Ca}-69,53$, and 60. In general, fertility levels were considered to be: $\mathrm{P}$-low, $\mathrm{K}$-medium high, $\mathrm{Mg}$-low to high, and $\mathrm{Ca}-$ medium.

Tomatoes were grown in a greenhouse in 162-cell Todd planter flats (Speedling, Sun City, Fla.) with a cell volume of $18 \mathrm{~cm}^{3}$ using a 1 peat $: 1$ vermiculite (v/v) medium. A soluble high-P complete fertilizer (10 g.liter ${ }^{-1}$ at 1 liter/flat) was applied each week. Plants were acclimated in a coldframe.

Fertilizer treatments (Table 1) consisted of various placement combinations of $\mathrm{N}, \mathrm{P}$, and $\mathrm{K}$, including complete broadcast preplant $(\mathrm{Br})$, banding at transplanting $(\mathrm{Ba})$, broadcasting preplant combined with banding at transplanting $(\mathrm{Br} / \mathrm{Ba})$, banding and sidedressing combined $(\mathrm{Ba} / \mathrm{Sd})$, wider (see below) bands or four bands at transplanting (WBa or $4 \mathrm{Ba}$ ), and an unfertilized control. Nitrogen, $\mathrm{P}$, and $\mathrm{K}$ fertilizer sources were urea, triple superphosphate, and muriate of potash, respectively.

All broadcast fertilizer was applied over the plot area and incorporated to $\approx 15 \mathrm{~cm}$ with a rotovator. Transplanting was 
Table 1. Fertilizer placement effects on yield responses of 'Count II' tomatoes (1986-88).

\begin{tabular}{|c|c|c|c|c|c|}
\hline \multirow[b]{2}{*}{ Treatment $^{z, y}$} & \multirow{2}{*}{$\begin{array}{c}\text { Total } \\
\text { yield } \\
\left(\mathrm{t} \cdot \mathrm{ha}^{-1}\right)^{\mathbf{x}}\end{array}$} & \multirow{2}{*}{$\begin{array}{c}\text { Fruit } \\
\text { wt } \\
(\mathrm{g})^{\mathbf{x}}\end{array}$} & $\begin{array}{l}\text { Large } \\
\text { fruit }\end{array}$ & $\begin{array}{l}\text { Ripe } \\
\text { fruit }\end{array}$ & \multirow{2}{*}{$\begin{array}{c}\text { Vine } \\
\text { wt } \\
\left(\mathrm{t} \cdot \mathrm{ha}^{-1}\right)^{\prime}\end{array}$} \\
\hline & & & \multicolumn{2}{|c|}{$(\%)^{x}$} & \\
\hline Control & $61.0 \mathrm{c}$ & 119 & $39.3 \mathrm{a}$ & $31.9 \mathrm{ab}$ & $8.1 \mathrm{c}$ \\
\hline $112 \mathrm{Br}$ & $61.3 \mathrm{c}$ & b 109 & $28.1 \mathrm{c}$ & $32.3 \mathrm{ab}$ & $8.8 \mathrm{bc}$ \\
\hline $112 \mathrm{Ba}$ & $76.0 \mathrm{ab}$ & $a b^{114}$ & $29.8 \mathrm{bc}$ & $34.5 \mathrm{a}$ & $9.5 \mathrm{abc}$ \\
\hline $224 \mathrm{Br}$ & $70.4 \mathrm{~b}$ & b $^{109}$ & $26.3 \mathrm{c}$ & $32.8 \mathrm{ab}$ & $10.0 \mathrm{ab}$ \\
\hline $56 \mathrm{Br} / 56 \mathrm{Ba}$ & $71.7 \mathrm{ab}$ & $\mathrm{ab}^{112}$ & $29.2 \mathrm{bc}$ & $34.6 \mathrm{a}$ & $10.2 \mathrm{ab}$ \\
\hline $56 \mathrm{Ba} / 56 \mathrm{Sd} 1$ & $71.0 \mathrm{ab}$ & $b^{108}$ & $26.1 \mathrm{c}$ & $32.6 \mathrm{ab}$ & $8.8 \mathrm{bc}$ \\
\hline $56 \mathrm{Ba} / 56 \mathrm{Sd} 2$ & $79.3 \mathrm{a}$ & $\mathrm{ab}$ & $25.7 \mathrm{c}$ & $30.0 \mathrm{~b}$ & $10.6 \mathrm{a}$ \\
\hline $112 \mathrm{WBa}$ & $75.9 \mathrm{ab}$ & $a b^{114}$ & $31.7 \mathrm{bc}$ & $31.9 \mathrm{ab}$ & $9.8 \mathrm{abc}$ \\
\hline $1124 \mathrm{Ba}$ & $78.0 \mathrm{ab}$ & $a b{ }^{116}$ & $35.3 \mathrm{ab}$ & $33.4 \mathrm{ab}$ & $10.5 \mathrm{ab}$ \\
\hline LSD & 8.7 & 10 & 6.7 & 4.4 & 1.7 \\
\hline
\end{tabular}

${ }^{2} \mathrm{~N}, \mathrm{P}$, and $\mathrm{K}$ rates $\left(\mathrm{kg} \cdot \mathrm{ha}^{-1}\right)$.

${ }^{\mathrm{Br}}=$ broadcast, $\mathrm{Ba}=$ banded, $\mathrm{Sd}=$ sidedressed once $(1)$ or twice (2), $\mathrm{WBa}=$ wide bands, $4 \mathrm{Ba}=$ four bands, two on each side.

'Mean separation within each column by Fisher's protected LSD test, $P=0.05$.

done with a single-row transplanter using in-row spacing of 0.30 $\mathrm{m}$ in rows $1.52 \mathrm{~m}$ apart.

All banded fertilizer treatments, except the $112 \mathrm{WBa}$ and $4 \mathrm{Ba}$ treatments, were applied in double bands $10 \mathrm{~cm}$ on each side of the plants and $10 \mathrm{~cm}$ deep, The $56 \mathrm{Ba} / 56 \mathrm{Sd} 1$ and $\mathrm{Sd} 2$ treatments combined banding with one or two sidedressings. The $112 \mathrm{WBa}$ treatment was applied $15 \mathrm{~cm}$ on each side of the plants (wide bands), while the 112 4Ba treatment was applied in four bands, two on each side 10 and $30 \mathrm{~cm}$ from the plants. All banded treatments were applied immediately after transplanting using a tractor-mounted belt planter. Sidedressing in the $56 \mathrm{Ba} /$ $56 \mathrm{Sd} 1$ treatment was similar to banding being applied as close to the plants as feasible $\approx 4$ weeks after transplanting. In the 56 $\mathrm{Ba} / 56 \mathrm{Sd} 2$ treatment, a second sidedressing was applied 2 weeks later.

In each plot, 15 plants were designated for data collection, leaving guard plants on each end. Plants that were in poor condition were replaced, within 10 days of transplanting, with comparable plants grown on the ends of the rows to create a uniform stand.

Leaf samples, consisting of the most recently matured leaf (petiole and blade), from 10 plants were selected from each plot when the first fruit cluster was forming. They were cleaned by dipping in detergent solution, tap water, and in three successive distilled water rinses. Leaf samples were dried at $60 \mathrm{C}$ and ground to pass through a l-mm screen. All samples were analyzed for concentrations of nine elements; $\mathrm{N}$ through the use of an autoanalyzer with manual digestion (Isaac and Johnson, 1976); and $\mathrm{P}, \mathrm{K}, \mathrm{Ca}, \mathrm{Mg}, \mathrm{Mn}, \mathrm{Cu}, \mathrm{B}$, and $\mathrm{Zn}$ using an ICP emission spectrometer (Dahlquist and Knoll, 1978).

In determining elemental plant content of the above-ground parts in 1987-88, three equally-spaced plants from each plot were chosen at harvest time. Plants were cut at ground level and fruits were removed. Fresh weights of vines and fruit were recorded separately. Vines were cleaned and dried using the same procedures as described for leaf samples, and dry weights were recorded. Plant samples were first ground to pass through a coarse screen $(2 \mathrm{~mm})$, thoroughly mixed, and a subsample was ground to pass through a 1-mm screen.

A representative sample made up of $20 \%$ of the fruit in each plot of three plants was selected, taking into consideration the differences in size and maturity. These were cleaned as described for leaf samples. Each fruit sample was made up of onequarter of each fruit in this sample. Fruit samples were freezedried and dry weights were recorded. After drying, fruits were ground to pass a 1-mm screen. Plant and fruit samples were analyzed separately for nine elements using methods described for leaf samples. The total quantity of each element found in the vines and fruit from the three-plant sample from each plot was calculated by multiplying by the respective dry weights. These were combined to show the total plant content, which is shown on a per-plant basis. The plant contents of $\mathrm{N}, \mathrm{P}$, and $\mathrm{K}$ over the control amount for each treatment of the fertilizer applied were compared with the quantities of these elements applied in the fertilizer. Control plot values were used as a measure of indigenous nutrient availability.

The remaining 12 plants in each plot were harvested twice. In both harvests, ripe, pink, and mature-green fruits were picked and graded by diameter into: extra large $(>7.3 \mathrm{~cm})$, large $(6.4$ to $7.2 \mathrm{~cm})$, medium $(5.7$ to $6.3 \mathrm{~cm})$, and small $(<5.6 \mathrm{~cm})$. The number and weight of each size of ripe, pink, and mature-green fruits were recorded. In the last harvest, the number and weight of immature green and rotten fruits and vine weights were also obtained.

Field and leaf, plant, and fruit analyses data were subjected to an analysis of variance and Fisher's protected LSD test at the 0.05 level. Simple correlation coefficients were determined to show the degree of association between concentration and content (SAS, 1985).

\section{Results}

Growth responses. There were no significant year $\times$ fertilizer interactions for yield responses. Total yields of all treatments, except $112 \mathrm{Br}$, were higher than the control (Table 1). Yield for the $112 \mathrm{Ba}$ treatment was $24 \%$ higher than the same rate broadcast and similar to those for $224 \mathrm{Br}$, the three combination placements, $112 \mathrm{WBa}$, and $112 \mathrm{4Ba}$. Total yield for $56 \mathrm{Ba} / 56$ $\mathrm{Sd} 2$ was higher than that for $224 \mathrm{Br}$. Mean fruit weight was lower in the $112 \mathrm{Br}, 224 \mathrm{Br}$, and $56 \mathrm{Ba} / 56 \mathrm{Sd} 1$ treatments than the control. All treatments, except $1124 \mathrm{Ba}$, had a smaller percentage of large fruit than the control. No treatment affected percentage of ripe fruit, except $112 \mathrm{Ba}$ and $56 \mathrm{Br} / 56 \mathrm{Ba}$, which had a higher percentage of ripe fruit than $56 \mathrm{Ba} / 56 \mathrm{Sd}$. Vine weights showed trends similar to those of total yields.

Leaf nutrient concentration. In considering leaf analysis (Table 2), there were significant year $\times$ fertilizer interactions only for leaf $\mathrm{Mg}, \mathrm{Mn}$, and $\mathrm{Cu}$. Leaf $\mathrm{N}$ was higher in all treatments than in the control and was higher in the $56 \mathrm{Ba} / 56 \mathrm{Sd} 2$ than in most other treatments but was not different from the $224 \mathrm{Br}$ or $56 \mathrm{Ba} / 56 \mathrm{Sd} 1$ treatments. Leaf $\mathrm{P}$ was also higher in all treatments than in the control. Phosphorus applications involving only banding or sidedressing tended to lead to higher leaf $\mathrm{P}$ concentration than those involving broadcasting, except for 224 Br. Leaves in the $56 \mathrm{Ba} / 56 \mathrm{Sd} 2$ treatment had a higher leaf $\mathrm{P}$ level than those from most other treatments, and it was similar to those from $224 \mathrm{Br}$ and $56 \mathrm{Ba} / 56 \mathrm{Sdl}$. Leaf $\mathrm{K}$ was higher in the $112 \mathrm{Ba}$ and $56 \mathrm{Ba} / 56 \mathrm{Sd} 2$ treatments than $112 \mathrm{Br}$. Compared 
Table 2. Fertilizer placement effects on leaf elemental concentrations of 'Count II' tomatoes (1986-88).

\begin{tabular}{|c|c|c|c|c|c|c|c|c|c|}
\hline \multirow[b]{2}{*}{ Treatment $^{\mathbf{z}, \mathbf{y}}$} & $\mathrm{N}$ & $\mathbf{P}$ & $\mathrm{K}$ & $\mathrm{Ca}$ & $\mathrm{Mg}$ & $\mathrm{Mn}$ & $\mathrm{Cu}$ & $\mathrm{B}$ & $\mathrm{Zn}$ \\
\hline & \multicolumn{5}{|c|}{$(\%)^{x}$} & \multicolumn{4}{|c|}{$\left(\mu \mathrm{g} \cdot \mathrm{g}^{-1}\right)^{x}$} \\
\hline Control & $3.68 \mathrm{c}$ & $0.24 \mathrm{~d}$ & $3.37 \mathrm{bc}$ & $4.02 \mathrm{a}$ & $0.86 \mathrm{a}$ & $165 \mathrm{f}$ & $7.8 \mathrm{a}$ & $27 a$ & $31 \mathrm{a}$ \\
\hline $112 \mathrm{Br}$ & $4.23 \mathrm{~b}$ & $0.28 \mathrm{c}$ & $3.29 \mathrm{c}$ & $3.78 a b$ & $0.86 \mathrm{a}$ & 207 ef & $6.3 \mathrm{~b}$ & $24 \mathrm{~b}$ & $26 \mathrm{bc}$ \\
\hline $112 \mathrm{Ba}$ & $4.18 \mathrm{~b}$ & $0.30 \mathrm{bc}$ & $3.60 \mathrm{ab}$ & $3.77 \mathrm{ab}$ & $0.77 \mathrm{bc}$ & 371 a & $5.6 \mathrm{c}$ & $25 \mathrm{ab}$ & $25 \mathrm{~cd}$ \\
\hline $224 \mathrm{Br}$ & $4.41 \mathrm{ab}$ & $0.32 \mathrm{ab}$ & $3.55 \mathrm{abc}$ & $3.67 \mathrm{bc}$ & $0.81 \mathrm{ab}$ & $325 \mathrm{ab}$ & $5.8 \mathrm{bc}$ & $25 \mathrm{ab}$ & $26 \mathrm{bcd}$ \\
\hline $56 \mathrm{Br} / 56 \mathrm{Ba}$ & $4.22 \mathrm{~b}$ & $0.28 \mathrm{c}$ & $3.47 \mathrm{abc}$ & $3.78 \mathrm{ab}$ & $0.82 \mathrm{ab}$ & $227 \mathrm{de}$ & $5.8 \mathrm{bc}$ & $24 \mathrm{~b}$ & $26 \mathrm{bcd}$ \\
\hline $56 \mathrm{Ba} / 56 \mathrm{Sd} 1$ & $4.33 \mathrm{ab}$ & $0.32 \mathrm{ab}$ & $3.48 \mathrm{abc}$ & $3.43 \mathrm{~cd}$ & $0.73 \mathrm{c}$ & 298 bc & $5.4 \mathrm{c}$ & $24 \mathrm{~b}$ & $24 \mathrm{~cd}$ \\
\hline $56 \mathrm{Ba} / 56 \mathrm{Sd} 2$ & $4.60 \mathrm{a}$ & $0.34 \mathrm{a}$ & $3.67 \mathrm{a}$ & $3.24 \mathrm{~d}$ & $0.71 \mathrm{c}$ & $318 \mathrm{ab}$ & $5.8 \mathrm{bc}$ & $24 \mathrm{~b}$ & $28 \mathrm{ab}$ \\
\hline $112 \mathrm{WBa}$ & $4.23 \mathrm{~b}$ & $0.30 \mathrm{bc}$ & $3.46 \mathrm{abc}$ & $3.55 \mathrm{bcd}$ & $0.75 \mathrm{bc}$ & $351 \mathrm{ab}$ & $5.8 \mathrm{bc}$ & $25 \mathrm{ab}$ & $26 \mathrm{bcd}$ \\
\hline $1124 \mathrm{Ba}$ & $4.24 \mathrm{~b}$ & $0.30 \mathrm{bc}$ & $3.45 \mathrm{abc}$ & $3.86 \mathrm{ab}$ & $0.81 \mathrm{ab}$ & $262 \mathrm{~cd}$ & $5.4 \mathrm{c}$ & $24 \mathrm{~b}$ & $23 \mathrm{~d}$ \\
\hline LSD & 0.27 & 0.03 & 0.27 & 0.32 & 0.07 & 55 & 0.6 & 2 & 3 \\
\hline
\end{tabular}

${ }^{2} \mathrm{~N}, \mathrm{P}$, and $\mathrm{K}$ rates $\left(\mathrm{kg} \cdot \mathrm{ha}^{-1}\right)$.

${ }^{\mathrm{Br}}=$ broadcast, $\mathrm{Ba}=$ banded, $\mathrm{Sd}=$ sidedressed once $(1)$ or twice $(2), \mathrm{WBa}=$ wide bands, $4 \mathrm{Ba}=$ four bands, two on each side.

${ }^{x}$ Mean separation within each group by Fisher's protected LSD test, $P=0.05$.

to the control, leaf $\mathrm{Ca}$ was lower for $224 \mathrm{Br}$, the two $\mathrm{Sd}$, and the WBa treatments. Leaf $\mathrm{Mg}$ for $112 \mathrm{Ba}$, the two sidedressed applications, and WBa was lower than in the control.

Leaf $\mathrm{Mn}$ was increased by $79 \%$ in the $112 \mathrm{Ba}$ treatment compared to $112 \mathrm{Br}$. Leaf $\mathrm{Mn}$ for $112 \mathrm{Ba}$ was similar to that for $224 \mathrm{Br}, 56 \mathrm{Ba} / 56 \mathrm{Sd} 2$, and $112 \mathrm{WBa}$ and distinctly higher than for the combined placements at the same rate or for $1124 \mathrm{Ba}$. Trends were similar for all 3 years although the scope of the differences varied. Leaf $\mathrm{Cu}, \mathrm{B}$, and $\mathrm{Zn}$ tended to be lower in all treatments than in the control, but there were no important differences among placements.

Fruit nutrient concentration. There were no significant year $\times$ fertilizer interactions for fruit analyses. Fruit $\mathrm{N}$ was higher in the $224 \mathrm{Br}, 56 \mathrm{Ba} / 56 \mathrm{Sd} 2$, and 112 4Ba treatments than in the control (Table 3). The $\mathrm{P}$ and $\mathrm{K}$ concentrations tended to be higher in all treatments than in the control, but there were no important differences between placements. Fruit $\mathrm{Ca}$ was lower for the $112 \mathrm{Ba}$ and the two sidedressed applications than for the control, while fruit $\mathrm{Mg}$ was not affected. Fruit Mn was higher than in the control in all treatments except for $112 \mathrm{Br}$ and 56 $\mathrm{Br} / 56 \mathrm{Ba}$. Fruit $\mathrm{Mn}$ was higher in $112 \mathrm{WBa}$ than in 112 4Ba. There were no important effects on fruit $\mathrm{Cu}, \mathrm{B}$, or $\mathrm{Zn}$.

Plant nutrient content. Considering plant content (Table 4), only $\mathrm{N}, \mathrm{P}, \mathrm{K}, \mathrm{Mn}, \mathrm{Cu}$, and $\mathrm{B}$ were affected by the treatments. The year $\times$ fertilizer interaction was significant only for plant
Mn content. Nitrogen content was higher in all treatments than in the control, except for $112 \mathrm{Br}$ and $56 \mathrm{Br} / 56 \mathrm{Ba}$. Phosphorus content was higher for all treatments than for the control. Phosphorus content was about equal for $56 \mathrm{Ba} / 56 \mathrm{Sd} 2,112 \mathrm{Ba}, 56$ $\mathrm{Ba} / 56 \mathrm{Sd} 1$, and $1124 \mathrm{Ba}$ and was higher for these than for the $56 \mathrm{Br} / 56 \mathrm{Ba}$ applications. Potassium content was higher in all treatments than in the control, except for $112 \mathrm{Br}, 56 \mathrm{Br} / 56 \mathrm{Ba}$, and $112 \mathrm{WBa}$. Plants in all treatments, except $112 \mathrm{Br}$, were higher in Mn content than in the control. The Mn content tended to be higher in banded, sidedressed, and higher rate treatments, but differences were greater in 1987 than in 1988. There were no meaningful treatment differences between contents of $\mathrm{Cu}$, $\mathrm{B}$, or Zn.

Efficiency of nutrient uptake. The efficiency of fertilizer uptake compares the total N, P, or K contents of plants and fruits with the amounts of these elements applied in the fertilizer treatments (Table 5). The $112 \mathrm{Ba}, 56 \mathrm{Ba} / 56 \mathrm{Sd} 1$, and 112 4Ba treatments led to higher percentages of recovery of N, P, and $\mathrm{K}$ than the other treatments. Percentage recovery tended to be lower in treatments involving broadcasting and in those with higher rates or wide bands.

\section{Discussion}

Only with $\mathrm{N}, \mathrm{P}, \mathrm{K}$, and $\mathrm{Mn}$ did the placement treatments result in greater differences in total plant contents than in leaf

Table 3. Fertilizer placement effects on fruit elemental concentrations of 'Count II' tomatoes (1986438).

\begin{tabular}{|c|c|c|c|c|c|c|c|c|c|}
\hline \multirow[b]{2}{*}{ Treatment ${ }^{z, y}$} & $\mathrm{~N}$ & $\mathrm{P}$ & $\mathrm{K}$ & $\mathrm{Ca}$ & $\mathrm{Mg}$ & $\mathrm{Mn}$ & $\mathrm{Cu}$ & B & $\mathrm{Zn}$ \\
\hline & \multicolumn{5}{|c|}{$(\%)^{x}$} & \multicolumn{4}{|c|}{$\left(\mu g \cdot g^{-1}\right)^{x}$} \\
\hline Control & $2.86 \mathrm{~b}$ & $0.36 \mathrm{c}$ & $3.87 \mathrm{~b}$ & $0.23 \mathrm{a}$ & $0.21 \mathrm{ab}$ & $25 \mathrm{e}$ & $1.6 \mathrm{abc}$ & $12 \mathrm{ab}$ & $20 \mathrm{ab}$ \\
\hline $112 \mathrm{Br}$ & $06 \mathrm{ab}$ & $0.41 \mathrm{ab}$ & $4.22 \mathrm{ab}$ & $0.22 \mathrm{ab}$ & 0. & 27 cde & & 13 & $21 \mathrm{ab}$ \\
\hline $112 \mathrm{Ba}$ & $04 a b$ & 0.41 & 4.16 & 0.19 & $0.21 \mathrm{ab}$ & 32 & & 12 & $20 \mathrm{ab}$ \\
\hline $224 \mathrm{Br}$ & $3.15 \mathrm{a}$ & $0.42 \mathrm{a}$ & $4.23 \mathrm{ab}$ & $0.20 \mathrm{abc}$ & $0.21 \mathrm{ab}$ & 30 & 1.4 & 12 & 29 a \\
\hline $56 \mathrm{Br} / 56 \mathrm{Ba}$ & $3.06 \mathrm{ab}$ & $0.39 \mathrm{~b}$ & 4.04 & $0.20 \mathrm{abc}$ & $0.21 \mathrm{ab}$ & 26 & & & $20 \mathrm{ab}$ \\
\hline $6 \mathrm{Ba} / 56 \mathrm{Sd} 1$ & $3 \mathrm{ab}$ & $0.41 \mathrm{abc}$ & $4.03 \mathrm{ab}$ & $0.19 \mathrm{bc}$ & $0.20 \mathrm{~b}$ & $29 \mathrm{bcd}$ & 1.3 & $12 \mathrm{ab}$ & $18 \mathrm{~b}$ \\
\hline $6 \mathrm{Ba} / 56 \mathrm{Sd} 2$ & 3 & 0.45 & $4.20 \mathrm{ab}$ & $0.18 \mathrm{c}$ & $0.20 \mathrm{~b}$ & 34 & & 12 & \\
\hline $112 \mathrm{WBa}$ & $3.04 \mathrm{ab}$ & $0.41 \mathrm{ab}$ & $4.13 \mathrm{ab}$ & $0.21 \mathrm{ab}$ & $0.21 \mathrm{ab}$ & $34 \mathrm{a}$ & $1.5 \mathrm{abc}$ & $13 \mathrm{ab}$ & $21 \mathrm{ab}$ \\
\hline 112 & 211 & $0.42 a b$ & $4.26 \mathrm{a}$ & $0.21 \mathrm{ab}$ & $0.22 \mathrm{a}$ & $28 \mathrm{bcd}$ & $1.9 \mathrm{a}$ & $13 \mathrm{ab}$ & $19 \mathrm{~b}$ \\
\hline LSD & 0.24 & 0.05 & 0.37 & 0.03 & 0.02 & 4 & 0.5 & 1 & 9 \\
\hline
\end{tabular}

${ }^{2} \mathrm{~N}, \mathrm{P}$, and $\mathrm{K}$ rates $\left(\mathrm{kg}^{\circ} \mathrm{ha}^{-1}\right)$.

$\mathrm{y} \mathrm{Br}=$ broadcast, $\mathrm{Ba}=$ banded, $\mathrm{Sd}=$ sidedressed once (1) or twice (2), $\mathrm{WBa}=$ wide bands, $4 \mathrm{Ba}=$ four bands, two on each side.

${ }^{x}$ Mean separation within each column by Fisher's protected LSD test, $P=0.05$. 
Table 4. Fertilizer placement effects on plant and fruit elemental contents of 'Count II' tomatoes (1987-88).

\begin{tabular}{|c|c|c|c|c|c|c|c|c|c|}
\hline \multirow[b]{2}{*}{ Treatment ${ }^{2, y}$} & $\mathrm{~N}$ & $\mathbf{P}$ & $\mathrm{K}$ & $\mathrm{Ca}$ & $\mathrm{Mg}$ & $\mathrm{Mn}$ & $\mathrm{Cu}$ & B & $\mathrm{Zn}$ \\
\hline & \multicolumn{5}{|c|}{$(g / \text { plant })^{x}$} & \multicolumn{4}{|c|}{$(\mathrm{mg} / \text { plant })^{\mathbf{x}}$} \\
\hline Control & $5.60 \mathrm{~b}$ & $0.55 \mathrm{~d}$ & $7.25 \mathrm{c}$ & $4.97 \mathrm{a}$ & $1.51 \mathrm{a}$ & $24.9 \mathrm{~d}$ & $0.79 \mathrm{ab}$ & $4.15 \mathrm{c}$ & $6.88 \mathrm{a}$ \\
\hline $112 \mathrm{Br}$ & $6.82 \mathrm{ab}$ & $0.76 \mathrm{bc}$ & $8.74 \mathrm{abc}$ & $5.58 \mathrm{a}$ & $1.72 \mathrm{a}$ & $33.3 \mathrm{~cd}$ & $0.83 \mathrm{ab}$ & $4.69 \mathrm{abc}$ & $7.66 \mathrm{a}$ \\
\hline $112 \mathrm{Ba}$ & $7.51 \mathrm{a}$ & $0.88 \mathrm{ab}$ & $9.85 \mathrm{a}$ & $5.97 \mathrm{a}$ & $1.68 \mathrm{a}$ & $55.6 \mathrm{a}$ & $0.83 a b$ & $5.28 \mathrm{ab}$ & $7.93 \mathrm{a}$ \\
\hline $224 \mathrm{Br}$ & $7.19 \mathrm{a}$ & $0.82 \mathrm{bc}$ & $9.32 \mathrm{ab}$ & $5.22 \mathrm{a}$ & $1.65 \mathrm{a}$ & $48.2 \mathrm{ab}$ & $0.78 \mathrm{ab}$ & $4.72 a b c$ & $7.47 \mathrm{a}$ \\
\hline $56 \mathrm{Br} / 56 \mathrm{Ba}$ & $6.50 \mathrm{ab}$ & $0.71 \mathrm{c}$ & $7.98 \mathrm{bc}$ & $5.32 \mathrm{a}$ & $1.57 \mathrm{a}$ & $35.0 \mathrm{~cd}$ & $0.72 a b$ & $4.44 \mathrm{bc}$ & $6.50 \mathrm{a}$ \\
\hline $56 \mathrm{Ba} / 56 \mathrm{Sd} 1$ & $7.59 \mathrm{a}$ & $0.88 \mathrm{ab}$ & $9.58 \mathrm{ab}$ & $5.92 \mathrm{a}$ & $1.70 \mathrm{a}$ & $54.1 \mathrm{ab}$ & $0.84 \mathrm{a}$ & $5.40 \mathrm{a}$ & $7.29 \mathrm{a}$ \\
\hline $56 \mathrm{Ba} / 56 \mathrm{Sd} 2$ & $7.51 \mathrm{a}$ & $0.97 \mathrm{a}$ & $10.01 \mathrm{a}$ & $5.10 \mathrm{a}$ & $1.49 \mathrm{a}$ & 56.5 a & $0.68 \mathrm{~b}$ & $5.02 \mathrm{abc}$ & $7.36 \mathrm{a}$ \\
\hline $112 \mathrm{WBa}$ & $6.86 \mathrm{a}$ & $0.78 \mathrm{bc}$ & $8.71 \mathrm{abc}$ & 5.31 a & $1.60 \mathrm{a}$ & $52.5 \mathrm{ab}$ & $0.69 a b$ & $4.82 \mathrm{abc}$ & $6.97 \mathrm{a}$ \\
\hline $1124 \mathrm{Ba}$ & $7.75 \mathrm{a}$ & $0.86 \mathrm{ab}$ & $10.03 \mathrm{a}$ & $5.91 \mathrm{a}$ & $1.78 \mathrm{a}$ & $42.0 \mathrm{bc}$ & $0.83 \mathrm{ab}$ & $5.21 \mathrm{ab}$ & $6.90 \mathrm{a}$ \\
\hline LSD & 1.26 & 0.14 & 1.64 & 1.29 & 0.38 & 12.2 & 0.16 & 0.91 & 1.50 \\
\hline
\end{tabular}

${ }^{\mathrm{z}} \mathrm{N}, \mathrm{P}$, and $\mathrm{K}$ rates $\left(\mathrm{kg} \cdot \mathrm{ha}^{-1}\right)$.

$\mathrm{y} \mathrm{Br}=$ broadcast, $\mathrm{Ba}=$ banded, $\mathrm{Sd}=$ sidedressed once $(1)$ or twice $(2), \mathrm{WBa}=$ wide bands, $4 \mathrm{Ba}=$ four bands, two on each side.

'Mean separation within each column by Fisher's protected LSD test, $P=0.05$.

Table 5. Fertilizer placement effects inefficiency of nutrient uptake of 'Count II' tomatoes (1987-88).

\begin{tabular}{|c|c|c|c|}
\hline \multirow[b]{2}{*}{ Treatment $z, y$} & $\mathrm{~N}$ & $\mathrm{P}$ & $\mathrm{K}$ \\
\hline & \multicolumn{3}{|c|}{$(\% \text { recovered })^{\mathbf{x}}$} \\
\hline Control & $0.0 \mathrm{bc}$ & $0.0 \mathrm{c}$ & $0.0 \mathrm{~d}$ \\
\hline $112 \mathrm{Br}$ & $18.0 \mathrm{ab}$ & $3.5 \mathrm{ab}$ & $23.4 a-c$ \\
\hline $112 \mathrm{Ba}$ & $31.2 \mathrm{a}$ & $5.8 \mathrm{a}$ & $44.7 \mathrm{a}$ \\
\hline $224 \mathrm{Br}$ & $12.5 \mathrm{bc}$ & $2.3 \mathrm{bc}$ & $17.2 \mathrm{bcc}$ \\
\hline $56 \mathrm{Br} / 56 \mathrm{Ba}$ & $11.7 \mathrm{bc}$ & $2.4 b$ & $8.8 \mathrm{~cd}$ \\
\hline $56 \mathrm{Ba} / 56 \mathrm{Sd} 1$ & $32.7 \mathrm{a}$ & $5.7 \mathrm{a}$ & $39.6 \mathrm{ab}$ \\
\hline $56 \mathrm{Ba} / 56 \mathrm{Sd} 2$ & $20.8 \mathrm{ab}$ & $5.0 \mathrm{a}$ & $31.8 \mathrm{abc}$ \\
\hline $112 \mathrm{WBa}$ & $18.8 \mathrm{ab}$ & $3.9 \mathrm{ab}$ & $22.9 a-c$ \\
\hline $1124 \mathrm{Ba}$ & $35.8 \mathrm{a}$ & $5.4 \mathrm{a}$ & $48.2 \mathrm{a}$ \\
\hline LSD & 20.9 & 2.4 & 25.5 \\
\hline
\end{tabular}

${ }^{2} \mathrm{~N}, \mathrm{P}$, and $\mathrm{K}$ rates $\left(\mathrm{kg} \cdot \mathrm{ha}^{-1}\right)$.

${ }^{\mathrm{y}} \mathrm{Br}=$ broadcast, $\mathrm{Ba}=$ banded, $\mathrm{Sd}=$ sidedressed once $(1)$ or twice (2), $\mathrm{WBa}=$ wide bands, $4 \mathrm{Ba}=$ four bands, two on each side.

'Mean separation within each column by Fisher's protected LSD test, $P=0.05$.

concentrations. For example, contents of $\mathrm{P}$ and $\mathrm{Mn}$ increased $75 \%$ and $209 \%$ for $56 \mathrm{Ba} / 56 \mathrm{Sd} 2$ compared to the control, whereas comparable increases in leaf concentrations were $43 \%$ and $93 \%$, respectively. Thus, for these elements, plant content was a more sensitive means of determining nutrient uptake than was leaf concentration. Only with $\mathrm{Mg}$ and $\mathrm{Mn}$ were leaf concentrations and plant contents highly correlated (data not shown). When contents of $\mathrm{N}, \mathrm{P}$, and $\mathrm{K}$ were compared with the quantities applied, percentages recovered were greater for banded or sidedressed treatments than for broadcast applications.

These results confirmed earlier work that showed that banding was much more effective than broadcasting in supplying nutrients and increasing yields. At least double the rate of fertilizer needed to be applied when it was broadcast rather than banded to realize a similar yield response. In these experiments, differences in uptake were determined more precisely through considering plant contents and recovery of applied fertilizer. However, banding higher rates increased Mn uptake substantially, as shown by both leaf concentrations and plant contents, suggesting that soil acidity had been increased in the root zone. This could potentially cause toxicity, especially where insufficient lime had been applied. If this occurrence is a potential problem, splitting the fertilizer between banding and sidedressing or using double the number of bands would significantly reduce the chances of toxicity.

Broadcasting has been the most common means of fertilizer application for tomato production in Pennsylvania. These results show that vegetable growers there, and in similar situations, can realize a substantial increase in production efficiency by adopting banding or banding/sidedressing placement methods, resulting in a distinct drop in fertilizer costs and reduced risk of fertilizer loss to ground water.

\section{Literature Cited}

Brown, L.D. and R.L. Carolus. 1965. An evaluation of fertilizer practice in relation to nutrient requirements of asparagus. J. Amer. Soc. Hort. Sci 86:332337.

Dahlquist, R.L. and J.W. Knoll. 1978. Inductively coupled plasma-atomic emission spectrometer: Analysis of biological materials and major, trace, and ultra trace elements. Applied Spectroscopy 39(1): 1-29.

Dahnke, W.C. 1988. Recommended chemical soil test procedures. North Dakota Agr. Expt. Sta. Bul. 499:1-37.

Farhoomand, M.B. and L.A. Peterson. 1968. Concentration and content. Agron. J. 60:708-709.

Hills, F. J., F.E. Broadbent, and O.A. Lorenz. 1983. Fertilizer nitrogen utilization by corn, tomato and sugarbeet. Agron. J. 75(3):423-426.

Hipp, B.W. 1970. Phosphorus requirements for tomatoes as influenced by placement. Agron. J. 62:203-206.

Isaac, R.A. and W.C. Johnson. 1976. Determination of nitrogen in plant tissue, using a block digester. J. Assn. Offic. Agr. Chem. 50:98-100.

Jarrell, W.M. and R.B. Beverly. 1981. The dilution effect in plant nutrition studies. Adv. Agron. 34: 197-224.

Jones, L.G. and G.F. Warren. 1954. The efficiency of various methods of application of P for tomatoes. Proc. Amer. Soc. Hort. Sci. 63:309-319.

Locascio, S.J., G.F. Warren, and G.E. Wilcox. 1960. The effect of P placement on uptake of $\mathrm{P}$ and growth of direct-seeded tomatoes. Proc. Amer. Soc. Hort. Sci. 76:503-514.

Miller, R. J., D.E. Rolston, R.S. Rauschkolb, and D.W. Wolfe. 1981. Labeled nitrogen uptake by drip-irrigated tomatoes. Agron. J. 73(2):265-270.

Palaniyandi, R. and C.B. Smith. 1978. Growth and nutrient interrelationships in snap beans as affected by several sources of potassium and magnesium. J. Amer. Soc. Hort. Sci. 103(1):109-113.

SAS, Institute, Inc. 1985. SAS user's guide: Statistics, version 5 ed. SAS Institute, Inc., Cary, N.C.

Smith, C. B., K.T. Demchak, and P.A. Ferretti. 1990. Fertilizer placement effects on growth responses and nutrient uptake of sweet corn, snapbeans, tomatoes and cabbage. Commun. Soil Sci. Plant Anal. 21(1, 2): 107-123.

Sweeney, D. W., D.A. Graetz, A.B. Bottcher, S.J. Locascio, and K.L. Campbell. 1987. Tomato yield and nitrogen recovery as influenced by irrigation method, nitrogen source and mulch. HortScience 22(1):27-29.

White, J.W. and J.A. Biernbaum. 1984. Effects of rootzone heating on elemental composition of calceolaria. J. Amer. Soc. Hort. Sci. 109(3):350-355. 